\title{
Dampak Transportasi Online pada Kinerja Keuangan Perusahan Transportasi Konvensional
}

\author{
Flafiana Sarihartati Agun 1, Diyah Sukanti Cahyaningsih ${ }^{2}$ \\ 1 Universitas Merdeka Malang Jl. Terusan Raya Dieng no 62-64, Malang, 65146, Indonesia \\ 2 Universitas Merdeka Malang Jl. Terusan Raya Dieng no 62-64, Malang, 65146, Indonesia
}

\begin{abstract}
PT Blue Bird, Tbk and PT Express Transindo Utama are conventional transportation service businesses, this research wants to assess the impact of financial performance as measured by Current Ratio, Cash Ratio, Debt to Asset Ratio, Debt to Equity Ratio, Fixed Asset Turn Over, Total Asset Turn Over, Net Profit Margin, Return on Assets, Return on Equity, Earning Per Share, and Price Earning Ratio before and after the emergence of online transportation. The data used is the 2012-2017 financial statements. With descriptive quantitative analysis the results are presented. at PT Express Transindo Utama, Tbk. shows that Current Ratio, Cash Ratio, Debt to Equity Ratio, Debt to Asset Ratio, Fixed Asset Turn Over, Total Asset Turn Over, Net Profit Margin, Return on Asset, Return On Equity, Earning Per Share and Price Earning Ratio have decreased after the advent of online transportation. The results of research at PT Blue Bird, Tbk. shows that Fixed Asset Turn Over, Total Asset Turn Over, Net Profit Margin, Return on Asset, Return On Equity, Earning Per Share and Price Earning Ratio decreased after the advent of online transportation. While Current Ratio, Cash Ratio, Debt to Asset Ratio, Debt to Equity Ratio increased. It was concluded that the emergence of online transportation does not always have a negative impact if conventional transportation service companies are able to adaptation.
\end{abstract}

Keywords: Conventional transportation; financial performance; financial ratios; online transportation

\begin{abstract}
ABSTRAK
PT Blue Bird, Tbk dan PT Express Transindo Utama merupakan usaha jasa transportasi konvensional, penelitian ini ingin mengkaji dampak kinerja keuangan yang diukur dengan Current Ratio, Cash Ratio, Debt to Asset Ratio, Debt to Equity Ratio, Fixed Asset Turn Over, Total Asset Turn Over, Net Profit Margin, Return on Assets, Return on Equity, Earning Per Share, dan Price Earning Ratio sebelum dan sesudah munculnya transportasi online. Data yang digunakan adalah laporan keuangan tahun 2012-2017. Dengan analisis kuantitatif deskriptif hasilnya disajikan. di PT Express Transindo Utama, Tbk. menunjukkan bahwa Current Ratio, Cash Ratio, Debt to Equity Ratio, Debt to Asset Ratio, Fixed Asset Turn Over, Total Asset Turn Over, Net Profit Margin, Return on Asset, Return On Equity, Earning Per Share dan Price Earning Ratio mengalami penurunan setelah munculnya transportasi online. Hasil penelitian di PT Blue Bird, Tbk. menunjukkan bahwa Fixed Asset Turn Over, Total Asset Turn Over, Net Profit Margin, Re-turn on Asset, Return On Equity, Earning Per Share dan Price Earning Ratio menurun setelah munculnya transportasi online. Sedangkan Current Ratio, Cash Ratio, Debt to Asset Ratio, Debt to Equity Ratio meningkat. Disimpulkan bahwa kemunculan transportasi online tidak selalu berdampak negatif jika perusahaan jasa transportasi konvensional mampu beradaptasi.
\end{abstract}

Kata Kunci: Transportasi konvensional; kinerja keuangan; rasio keuangan; transportasi online

\section{PENDAHULUAN}

Di era yang semakin modern dengan masyarakat yang mempunyai aktivitas beragam, indikator akan kepuasan terhadap transportasi umum mengalami perubahan. Masyarakat membutuhkan transportasi umum yang tidak hanya memberikan kenyamanan dalam pelayanan, melainkan juga mempunyai kemudahan dalam pemesanan dan ketepatan waktu. Transportasi online menawarkan kelebihan tersebut, pengguna bisa mengakses dengan mudah, murah, dan memberikan feedback langsung untuk menilai pelayanannya. Transportasi berbasis aplikasi menjadi daya tarik sendiri di kalangan masyarakat saat ini.

Awal tahun 2015, Gojek menjadi pemula bisnis trasportasi online Indonesia. Kehadiran aplikasi transportasi online ini, langsung menjadi salah satu bisnis yang paling populer di Indonesia, setelah itu muncullah grab taxi, uber taxi, dan lain-lain. Masyarakat yang pada awalnya khusus menengah ke atas, mulai beralih dari transportasi konvensional ke Grab Taxi dan Uber Taxi. Ada banyak alasan mengapa masyarakat mulai beralih ke transportasi online, beberapa diantaranya yaitu transportasi online dianggap lebih murah dan lebih praktis karena berbasis aplikasi dalam pemesanannya. Bukan hanya itu, keunggulan transportasi online adalah juga memiliki sistem pembayaran non-tunai yaitu dengan menggunakan kartu kredit 
maupun e-cash, seperti yang dimiliki Gojek dan Grab. Kita hanya perlu memastikan saldo kredit kita cukup untuk pembayaran, sehingga kita tidak perlu membawa uang yang banyak jika berpergian. Transportasi online juga menyediakan kode promo dalam pelayanannya sehingga pelanggan bisa membayar lebih murah dari biaya aslinya. Hal ini merupakan tantangan berat bagi pemain-pemain lama yaitu perusahaan layanan transportasi konvensional, perusahaan yang paling terkena dampak dari munculnya transportasi berbasis aplikasi ini adalah perusahaan yang bergerak dibidang layanan taksi. Munculnya pemain-pemain baru mengakibatkan market share pemain lama menjadi berkurang, penghasilan pengemudi merosot dan berimbas kepada kinerja saham perusahaan taksi. Tahun 2016, marak unjuk rasa terhadap munculnya transportasi online. Mulai dari Ibu Kota hingga ke daerah, pelaku transportasi konvensional masih belum bisa menerima keberadaan transportasi berbasis aplikasi. Dari sisi pemerintah, ini memunculkan berbagai kebijakan dalam rangka membatasi ruang gerak transportasi online, dan memberikan peluang pada transportasi konvensional untuk tetap bertahan. Peristiwa demonstrasi tersebut tidak hanya berimbas pada rusaknya fasilitas publik saja, namun juga pada lantai bursa saham. Menurut Ekonom dari Universitas Indonesia dan Samuel Sekuritas Lana Soelistianngsih, pergerakan saham dua emiten transportasi yaitu PT Blue Bird dan PT Express Transindo Utama tidak terlepas dari sentimen investor terkait demonstrasi menentang moda transportasi berbasis aplikasi (Kompas.com).

Selain itu berdasarkan penelitian yang dilakukan oleh Darmadi (2016) dengan judul penelitian “ Dampak Keberadaan Transportasi Online Terhadap Transportasi Angkutan Umum Lainnya di Kota Makassar", dengan menggunakan sumber data yang diperoleh melalui wawancara dan dokumentasi yang tersusun secara baik mengenai dampak layanan angkutan online menghasilkan kesimpulan bahwa transportasi konvensional mengalami penurunan order Lainnya di Kota Makassar", dengan menggunakan sumber data yang diperoleh melalui wawancara dan dokumentasi yang tersusun secara baik mengenai dampak layanan angkutan online menghasilkan kesimpulan bahwa transportasi konvensional mengalami penurunan orderan sehingga pendapatan setoran pengemudi berkurang setiap hari serta pendapatan perusahaan setiap bulannya tidak tercapai dan perusahaan diancam bangkrut.

Selanjutnya adalah penelitian yang dilakukan oleh Istianto dan Maulamin (2017) menyatakan bahwa transportasi online secara umum memiliki dampak sosial pada kehidupan masyarakat

Berdasarkan uraian diatas, maka dari itu, peneliti tertarik untuk melakukan penelitian terhadap kinerja keuangan perusahaan taksi konvensional di Indonesia sebelum dan sesudah munculnya transportasi online. Penelitian akan menganalisis kondisi kinerja keuangan perusahaan taksi konvensional dengan menggunakan analisis rasio keuangan yaitu rasio profitabilitas, rasio solvabilitas, rasio likuiditas, rasio aktivitas dan rasio pasar. Penelitian akan dilakukan terhadap PT Blue Bird, Tbk dan PT Express Transindo Utama, Tbk yang keduanya merupakan leader perusahan taksi di Indonesia..

\section{METODE}

Teknik pengumpulan data yang digunakan dalam penelitian ini adalah dokumentasi. Menurut Arikunto (2006) "Dokumentasi adalah mencari dan mengumpulkan data mengenai hal-hal yang berupa catatan, transkrip, buku, surat kabar, majalah, notulen, rapat, agenda, dan sebagainya.

\section{Teknik Analisis Data}

Dalam melakukan analisis kinerja keuangan perusahaan, maka peneliti melakukan hal berikut :

Melakukan perhitungan rasio keuangan dengan menggunakan rasio:

Rasio Likuiditas

Rasio Solvabilitas (Leverage Ratio)

Rasio Aktivitas (Activity Ratio)

Rasio Profitabilitas

Rasio Pasar

Data-data yang berwujud angka-angka hasil perhitungan dianalisis menggunakan analisis time series, yaitu analisis yang dilakukan dengan cara membandingkan rasio-rasio finansial suatu perusahaan dari suatu periode ke periode lainnya. Perbandingan antara rasio yang dicapai saat ini dengan rasio di masa lalu akan memperlihatkan apakah perusahaan mengalami kemajuan atau kemunduran. 


\section{HASIL}

\section{Rasio Likuiditas PT Blue Bird, Tbk dan PT Express Transindo Utama, Tbk sebelum dan sesudah munculnya transportasi online}

\section{Current Ratio}

Rasio lancar PT Express Transindo Utama sebelum munculnya transportasi online cenderung fluktuatif. Pada tahun 2012 nilai current ratio adalah sebesar 146\% dan turun menjadi $104 \%$ pada tahun 2013, penurunan tersebut karena persentase kenaikan utang lancar lebih tinggi dari persentase kenaikan aset lancar. Current ratio mengalami peningkatan kembali pada tahun 2014 yaitu menjadi sebesar 131\% kenaikan tersebut karena adanya peningkatan pada aset lancar yaitu piutang usaha dengan pihak ketiga. Jika dilihat dari tingkat rasio $100 \%$ perusahaan sudah cukup baik dalam memenuhi kewajiban jangka pendeknya. Jika dilihat dari rata-rata industri, nilai rata-rata Current Ratio sebesar $127 \%$ dan nilai ini juga sudah cukup baik karena berada diatas nilai rata-rata industri. Nilai current ratio PT Express Transindo Utama sesudah munculnya transportasi online kurang baik jika dibandingkan dengan sebelum munculnya transportasi online. Nilai current ratio tahun 2015 adalah sebesar 145\% dan naik menjadi $408 \%$ pada tahun 2016. Nilai current ratio yang mencapai $408 \%$ menunjukan kinerja yang kurang baik karena nilainya melebihi $200 \%$, nilai current ratio melebihi $200 \%$ mengindikasikan bahwa banyak aset lancar yang menganggur pada periode tersebut. Nilai current ratio pada tahun 2017 mengalami penurunan yang sangat drastis menjadi $85 \%$. Penurunan tersebut karena adanya penurunan aset lancar. Jika dilihat dari tingkat rasio 100\% nilai tersebut kurang baik karena nilai dibawah 100\%. Jika dilihat dari rata-rata industri, nilai rata-rata current ratio sebesar $213 \%$, nilai tersebut menunjukan kondisi yang masih baik karena berada diatas nilai rata-rata industri.

Tabel 1. Hasil perhitungan rasio likuiditas dan rata-rata industri sebelum dan sesudah munculnya transportasi online (2012-2017)

\begin{tabular}{|c|c|c|c|c|c|c|c|c|c|}
\hline \multirow{2}{*}{$\begin{array}{l}\text { Rasio } \\
\text { Likuiditas }\end{array}$} & \multirow{2}{*}{ Perusahaan } & \multicolumn{3}{|c|}{ SEBELUM } & \multirow{2}{*}{$\begin{array}{l}\text { Rata-rata } \\
\text { sebelum }\end{array}$} & \multicolumn{3}{|c|}{ SESUDAH } & \multirow{2}{*}{$\begin{array}{l}\text { Rata-rata } \\
\text { sesudah }\end{array}$} \\
\hline & & 2012 & 2013 & 2014 & & 2015 & 2016 & 2017 & \\
\hline \multirow{3}{*}{$\begin{array}{l}\text { Current } \\
\text { Ratio }\end{array}$} & TAXI & $146 \%$ & $104 \%$ & $131 \%$ & $127 \%$ & $145 \%$ & $408 \%$ & $85 \%$ & $213 \%$ \\
\hline & BIRD & $52 \%$ & $34 \%$ & $85 \%$ & $57 \%$ & $59 \%$ & $108 \%$ & $177 \%$ & $115 \%$ \\
\hline & $\begin{array}{l}\text { Rata-rata } \\
\text { Industri }\end{array}$ & $127 \%$ & $115 \%$ & $106 \%$ & $116 \%$ & $124 \%$ & $230 \%$ & $170 \%$ & $175 \%$ \\
\hline \multirow{3}{*}{ Cash Ratio } & TAXI & $40 \%$ & $55 \%$ & $42 \%$ & $46 \%$ & $32 \%$ & $9 \%$ & $2 \%$ & $14 \%$ \\
\hline & BIRD & $42 \%$ & $16 \%$ & $66 \%$ & $41 \%$ & $28 \%$ & $73 \%$ & $109 \%$ & $70 \%$ \\
\hline & $\begin{array}{l}\text { Rata-rata } \\
\text { Industri }\end{array}$ & $35 \%$ & $24 \%$ & $32 \%$ & $30 \%$ & $17 \%$ & $22 \%$ & $31 \%$ & $23 \%$ \\
\hline
\end{tabular}

Sumber: data diolah (2019)

Selanjutnya adalah rasio lancar pada PT Blue Bird. Rasio lancar pada tahun 2012 adalah sebesar 52\% dan turun menjadi 34\% pada tahun 2013. Penurunan tersebut diakibatkan karena menurunnya aset lancar pada tahun 2013. Rasio lancar mengalami peningkatan kembali pada tahun 2014 yaitu menjadi 85\%. Peningkatan tersebut karena adanya peningkatan pada aset lancar perusahaan yaitu kas dan setara kas. Jika dilihat dari tingkat rasio 100\% PT Blue Bird masih kurang baik dalam memenuhi kewajiban jangka pendeknya pada tahun 2012, 2013, dan 2014. Begitupun jika dilihat dari rata-rata industri nilai rata-rata Current Ratio sebelum munculnya transportasi online adalah sebesar $57 \%$ dan nilai ini kurang baik karena dibawah nilai rata-rata industri yaitu $116 \%$.

\section{Cash Ratio}

Cash ratio PT Express Transindo Utama pada tahun 2012 adalah sebesar 40\% dan naik menjadi 55\% pada tahun 2013. Kenaikan tersebut disebabkan oleh adanya peningkatan kas dan setara kas. Pada tahun 2014 turun kembali menjadi 42\%, penurunan tersebut disebabkan karena menurunnya kas dan setara kas. 
Jika dilihat dari tingkat rasio 100\% PT Express Transindo Utama pada tahun 2012, 2013, dan 2014 masih kurang baik dalam memenuhi kewajiban jangka pendeknya karena dibawah rasio $100 \%$. Namun, jika dilihat dari rata-rata industri, nilai rata-rata cash ratio sebesar $46 \%$ dan nilai ini sudah cukup baik karena diatas nilai rata-rata industri yaitu sebesar 30\%. Kondisi cash ratio PT Express Transindo Utama sesudah munculnya transportasi online semakin kurang baik jika dibandingkan dengan sebelum munculnya transportasi online. Nilai cash ratio pada tahun 2015 adalah sebesar $32 \%$ dan menurun menjadi $9 \%$ pada tahun 2016. Penurunan tersebut disebabkan karena terjadinya penurunan yang sangat drastis pada kas dan setara kas pada tahun 2016. Pada tahun 2017 menurun lagi menjadi 2\%. Jika dilihat dari rata-rata industri pun kinerja perusahaan juga kurang baik karena mempunyai nilai sebesar $14 \%$ dan dibawah nilai rata-rata industri.

\section{Rasio Solvabilitas PT Blue Bird, Tbk dan PT Express Transindo Utama, Tbk sebelum dan sesudah munculnya transportasi online}

\section{Debt to Asset Ratio (DAR)}

Debt to asset ratio PT Express Transindo Utama pada tahun 2012 adalah sebesar 61\% naik menjadi 63\% pada tahun 2013. Debt to asset ratio mengalami kenaikan kembali pada tahun 2014 yaitu menjadi $71 \%$. Peningkatan rasio selama tiga tahun tersebut karena adanya peningkatan pada utang jangka pendek maupun jangka panjang dari pihak perbankan dan lembaga keuangan lainnya. Hal ini menandakan bahwa semakin besar risiko terkait dengan operasional perusahaan setiap tahunnya. Namun besarnya Debt to Asset Ratio pada tahun 2012, 2013, dan 2014 masih tergolong baik karena angka rasio masih dibawah 100\%. Jika dilihat dari rata-rata industri, nilai rata-rata debt to asset ratio sebesar $65 \%$ juga tergolong baik karena nilainya dibawah nilai rata-rata industri yaitu sebesar 73\%. Nilai Debt to Asset Ratio PT Express Transindo Utama kurang baik setelah munculnya transportasi online. Hal ini bisa dilihat dari nilai DAR yang meningkat setiap tahunnya. Nilai DAR pada tahun 2015 adalah sebesar $68 \%$ naik menjadi $71 \%$ pada tahun 2016 dan naik lagi menjadi 88\% pada tahun 2017. Jika dilihat dari tingkat rasio 100\% nilai DAR pada tahun 2015, 2016, dan 2017 menunjukan kondisi yang masih baik karena nilai dibawah 100\%. Namun jika dilihat dari rata-rata industri, nilai rata-rata DAR sebesar $76 \%$ menunjukan kondisi yang kurang baik karena nilainya diatas rata-rata industri yaitu $57 \%$.

Tabel 2. Hasil perhitungan rasio solvabilitas dan rata-rata industri sebelum dan sesudah munculnya transportasi online (2012-2017)

\begin{tabular}{|c|c|c|c|c|c|c|c|c|c|}
\hline \multirow{2}{*}{$\begin{array}{l}\text { Rasio Solva- } \\
\text { bilitas }\end{array}$} & \multirow{2}{*}{ Perusahaan } & \multicolumn{3}{|c|}{ SEBELUM } & \multirow{2}{*}{$\begin{array}{l}\text { Rata-rata } \\
\text { sebelum }\end{array}$} & \multicolumn{3}{|c|}{ SESUDAH } & \multirow{2}{*}{$\begin{array}{l}\text { Rata-rata } \\
\text { sesudah }\end{array}$} \\
\hline & & 2012 & 2013 & 2014 & & 2015 & 2016 & 2017 & \\
\hline \multirow{3}{*}{$\begin{array}{l}\text { Debt to Asset } \\
\text { Ratio }\end{array}$} & TAXI & $61 \%$ & $63 \%$ & $71 \%$ & $65 \%$ & $68 \%$ & $71 \%$ & $88 \%$ & $76 \%$ \\
\hline & BIRD & $73 \%$ & $76 \%$ & $50 \%$ & $66 \%$ & $39 \%$ & $36 \%$ & $24 \%$ & $33 \%$ \\
\hline & $\begin{array}{l}\text { Rata-rata } \\
\text { Industri }\end{array}$ & $73 \%$ & $84 \%$ & $61 \%$ & $73 \%$ & $63 \%$ & $57 \%$ & $53 \%$ & $57 \%$ \\
\hline \multirow{3}{*}{$\begin{array}{l}\text { Debt to Equi- } \\
\text { ty Ratio }\end{array}$} & TAXI & $160 \%$ & $168 \%$ & $\begin{array}{l}240 \\
\%\end{array}$ & $189 \%$ & $213 \%$ & $247 \%$ & $715 \%$ & $392 \%$ \\
\hline & BIRD & $270 \%$ & $316 \%$ & $99 \%$ & $228 \%$ & $65 \%$ & $57 \%$ & $32 \%$ & $51 \%$ \\
\hline & $\begin{array}{l}\text { Rata-rata } \\
\text { Industri }\end{array}$ & $296 \%$ & $59 \%$ & $\begin{array}{l}167 \\
\%\end{array}$ & $174 \%$ & $206 \%$ & $67 \%$ & $168 \%$ & $147 \%$ \\
\hline
\end{tabular}

Sumber: data diolah (2019)

\section{Debt to Equity Ratio (DER)}

Debt to Equity Ratio pada PT Express Transindo Utama tahun 2012 adalah sebesar 160\% (besarnya modal yang dijadikan jaminan sebagai utang adalah sebesar 160\%) naik menjadi 168\% pada tahun 2013, lalu naik kembali pada tahun 2014 menjadi 240\%. Kenaikan tersebut disebabkan karena adanya peningkatan pada utang pinjaman jangka pendek dan jangka panjang dari Bank dan lembaga keuangan lainnya setiap tahunnya. Hal ini menandakan bahwa kinerja perusahaan pada tahun 2012, 2013, dan 2014 cukup buruk karena menunjukan DER yang lebih dari 100\% dan lebih dari 200\% pada tahun 2014, DER 
yang tinggi artinya perusahaan memiliki utang yang lebih besar dari modal perusahaan sehingga beban perusahaan semakin bertambah. Jika dilihat dari rata-rata industri, nilai rata-rata DER sebelum munculnya transportasi online adalah sebesar $189 \%$, nilai tersebut juga menunjukan kondisi yang kurang baik karena nilainya diatas rata-rata industri yaitu sebesar $174 \%$.

Nilai DER pada PT Express Transindo Utama semakin buruk jika dibandingkan dengan nilai sebelum munculnya transportasi online. Hal ini ditandai dengan semakin meningkat nilai DER setiap tahunnya dan melebihi 200\%. Nilai DER pada tahun 2015 sebesar 213\% naik menjadi 247\% pada tahun 2016 dan naik lagi menjadi $715 \%$ pada tahun 2017. Nilai-nilai tersebut menunjukan bahwa perusahaan bekerja dengan memiliki utang yang lebih besar dari modal perusahaan. Jika dilihat dari rata-rata industri, nilai rata-rata DER sesudah munculnya transportasi online pun menunjukan kinerja yang kurang baik karena nilainya di atas rata-rata industri.

Rasio Aktivitas PT Blue Bird, Tbk dan PT Express Transindo Utama, Tbk sebelum dan sesudah munculnya transportasi online

\section{Fixed Asset Turn Over (FATO)}

Fixed asset turn over pada PT Express Transindo Utama tahun 2012 adalah 0,45 lalu naik menjadi 0,49 tahun 2013 dan turun kembali menjadi 0,42 tahun 2014. Nilai fixed asset turn over pada tahun 2012, 2013, 2014 masih kurang baik karena nilainya masih dibawah 1. Hal ini menunjukan bahwa terdapat kapasitas terlalu besar atau ada banyak aktiva namun tidak bermanfaat. Jika dibandingkan dengan rata-rata industri nilai fixed asset turn over sebelum munculnya transportasi online adalah sebesar 0,42 , nilai tersebut pun kurang baik karena nilainya dibawah rata-rata industri yaitu sebesar 0,84 .

Tabel 3. Hasil perhitungan rasio aktivitas dan rata-rata industri sebelum dan sesudah munculnya transportasi online (2012-2017)

\begin{tabular}{|c|c|c|c|c|c|c|c|c|c|}
\hline \multirow{2}{*}{$\begin{array}{l}\text { Rasio Ak- } \\
\text { tivitas }\end{array}$} & \multirow{2}{*}{ Perusahaan } & \multicolumn{3}{|c|}{ SEBELUM } & \multirow{2}{*}{$\begin{array}{l}\text { Rata- } \\
\text { rata } \\
\text { sebelum }\end{array}$} & \multicolumn{3}{|c|}{ SESUDAH } & \multirow{2}{*}{$\begin{array}{l}\text { Rata- } \\
\text { rata } \\
\text { sesudah }\end{array}$} \\
\hline & & 2012 & 2013 & 2014 & & 2015 & 2016 & 2017 & \\
\hline \multirow{3}{*}{$\begin{array}{l}\text { Fixed asset } \\
\text { turn over }\end{array}$} & TAXI & 0,45 & 0,49 & 0,42 & 0,45 & 0,48 & 0,37 & 0,22 & 0,36 \\
\hline & BIRD & 1,01 & 0,9 & 0,86 & 0,92 & 0,88 & 0,78 & 0,75 & 0,8 \\
\hline & $\begin{array}{l}\text { Rata-rata } \\
\text { Industri }\end{array}$ & 0,88 & 0,85 & 0,78 & 0,84 & 0,81 & 0,85 & 0,68 & 0,78 \\
\hline \multirow{3}{*}{$\begin{array}{l}\text { Total Asset } \\
\text { Turn Over }\end{array}$} & TAXI & 0,29 & 0,32 & 0,3 & 0,3 & 0,34 & 0,24 & 0,15 & 0,24 \\
\hline & BIRD & 0,8 & 0,78 & 0,66 & 0,75 & 0,77 & 0,66 & 0,65 & 0,69 \\
\hline & $\begin{array}{l}\text { Rata-rata } \\
\text { Industri }\end{array}$ & 0,51 & 0,5 & 0,49 & 0,5 & 0,64 & 0,63 & 1,04 & 0,77 \\
\hline
\end{tabular}

Sumber: data diolah (2019)

Nilai fixed asset turn over PT Express Transindo Utama sesudah munculnya transportasi online semakin kurang baik. Hal ini ditandai dengan menurunnya nilai Fixed Asset Turn Over setiap tahunnya. Nilai Fixed Asset Turn Over pada tahun 2015 adalah sebesar 0,48 menjadi 0,37 pada tahun 2016 dan turun lagi menjadi 0,22 pada tahun 2017. Penurunan tersebut karena terjadinya penurunan pada aset tetap. Jika dilihat dari rata-rata industri, nilai rata-rata fixed asset turn over sesudah munculnya transportasi online juga menunjukan kondisi yang kurang baik karena nilainya dibawah rata-rata industri.

\section{Total Asset Turn Over (TATO)}

Total asset turn over pada PT Express Transindo Utama pada tahun 2012 adalah sebesar 0,29 naik menjadi 0,32 pada tahun 2013 dan turun kembali pada tahun 2014 menjadi sebesar 0,30. Kenaikan dan penurunan yang terjadi tidak terlalu signifikan. Nilai total asset turn over pada tahun 2012, 2013, dan 2014 juga menunjukan bahwa perusahaan belum cukup efisien menggunakan seluruh aktivanya dalam menghasilkan pendapatan karena nilainya masih dibawah 1. Jika dilihat dari rata-rata industri nilai total asset turn over sebelum munculnya transportasi online adalah sebesar 0,30 . Nilai tersebut pun tergolong 
kurang baik karena nilainya dibawah rata-rata industri yaitu sebesar 0,50 .

Nilai total asset turn over pada PT Express Transindo Utama sesudah munculnya transportasi online semakin kurang baik. Hal ini ditandai dengan menurunnya nilai asset turn over setiap tahunnya. Nilai TATO pada tahun 2015 adalah sebesar 0,34 turun menjadi 0,24 tahun 2016 dan turun lagi menjadi 0,15 tahun 2017. Penurunan tersebut disebabkan oleh turunnya aset tetap akibat dari perusahaan yang menjual aset tetapnya. Jika dilihat dari rata-rata industri, nilai TATO sesudah munculnya transportasi online sebesar 0,24 juga menunjukan kondisi yang kurang baik karena nilainya dibawah rata-rata industri.

\section{Rasio Profitabilitas PT Blue Bird, Tbk dan PT Express Transindo Utama, Tbk sebelum dan sesudah munculnya transportasi online}

\section{Net Profit Margin (NPM)}

Nilai net profit margin PT Express Transindo Utama pada tahun 2012 adalah sebesar 15\% (laba bersih atas penjualan sebesar 15\%) naik menjadi 19\% (laba bersih atas penjualan sebesar 19\%) pada tahun 2013. Kenaikan tersebut disebabkan karena adanya peningkatan laba pada tahun 2013, lalu menurun kembali pada tahun 2014 yaitu menjadi 13\% karena adanya penurunan laba bersih. Namun nilai dari net profit margin pada tahun 2012, 2013, dan 2014 sudah dicukup baik karena nilainya diatas dari 10\%. Jika dilihat dari rata-rata industri, nilai rata-rata net profit margin sebelum munculnya transportasi online adalah sebesar $16 \%$, nilai tersebut juga masih dalam kategori baik karena nilainya diatas rata-rata industri yaitu sebesar $-2,6 \%$.

Tabel 4. Hasil perhitungan rasio profitabilitas dan rata-rata industri sebelum dan sesudah munculnya transportasi online (2012-2017)

\begin{tabular}{|c|c|c|c|c|c|c|c|c|c|}
\hline \multirow{2}{*}{$\begin{array}{l}\text { Rasio } \\
\text { Profitabili- } \\
\text { tas }\end{array}$} & \multirow{2}{*}{ Perusahaan } & SEBEL & & & \multirow[t]{2}{*}{$\begin{array}{l}\text { Rata-rata } \\
\text { sebelum }\end{array}$} & \multicolumn{3}{|c|}{ SESUDAH } & \multirow[t]{2}{*}{$\begin{array}{l}\text { Rata-rata } \\
\text { sesudah }\end{array}$} \\
\hline & & 2012 & 2013 & 2014 & & 2015 & 2016 & 2017 & \\
\hline \multirow{3}{*}{$\begin{array}{l}\text { Net Profit } \\
\text { Margin }\end{array}$} & TAXI & $15 \%$ & $19 \%$ & $13 \%$ & $16 \%$ & $4 \%$ & $-30 \%$ & $-161 \%$ & $-62 \%$ \\
\hline & BIRD & $4 \%$ & $18 \%$ & $16 \%$ & $13 \%$ & $15 \%$ & $10 \%$ & $10 \%$ & $12 \%$ \\
\hline & $\begin{array}{l}\text { Rata-rata } \\
\text { Industri }\end{array}$ & $-2,50 \%$ & $-2,75 \%$ & $-2,50 \%$ & $-2,60 \%$ & $-6 \%$ & $16 \%$ & $-28 \%$ & $-6 \%$ \\
\hline \multirow{3}{*}{$\begin{array}{l}\text { Return On } \\
\text { Asset }\end{array}$} & TAXI & $4 \%$ & $6 \%$ & $4 \%$ & $5 \%$ & $1 \%$ & $-7 \%$ & $-24 \%$ & $-10 \%$ \\
\hline & BIRD & $11 \%$ & $14 \%$ & $10 \%$ & $12 \%$ & $12 \%$ & $7 \%$ & $6 \%$ & $8 \%$ \\
\hline & $\begin{array}{l}\text { Rata-rata } \\
\text { Industri }\end{array}$ & $1,00 \%$ & $0,00 \%$ & $-1,00 \%$ & $0,00 \%$ & $-4 \%$ & $28 \%$ & $2 \%$ & $8 \%$ \\
\hline \multirow{3}{*}{$\begin{array}{l}\text { Return On } \\
\text { Equity }\end{array}$} & TAXI & $12 \%$ & $17 \%$ & $13 \%$ & $14 \%$ & $4 \%$ & $-25 \%$ & $-199 \%$ & $-73 \%$ \\
\hline & BIRD & $42 \%$ & $59 \%$ & $21 \%$ & $41 \%$ & $19 \%$ & $11 \%$ & $9 \%$ & $13 \%$ \\
\hline & $\begin{array}{l}\text { Rata-rata } \\
\text { Industri }\end{array}$ & $-1 \%$ & $40 \%$ & $-3 \%$ & $12 \%$ & $-25 \%$ & $-49 \%$ & $-41 \%$ & $-38 \%$ \\
\hline
\end{tabular}

Sumber: data diolah (2019)

Sedangkan nilai net profit margin PT Express Transindo Utama setelah munculnya tranportasi online semakin buruk. Hal ini ditandai dengan nilai NPM yang semakin menurun setiap tahunnya. Nilai NPM tahun 2015 adalah sebesar $4 \%$ turun menjadi -30\% pada tahun 2016 dan turun lagi menjadi $-161 \%$ pada tahun 2017. Penurunan tersebut disebabkan karena terjadinya kerugian pada tahun 2016 dan 2017. Kerugian diakibatkan oleh persaingan bisnis yang semakin ketat pada tahun 2016 dan 2017 sehingga mengalami kerugian yang cukup besar. Jika dilihat dari rata-rata industri nilai NPM sesudah munculnya transportasi online juga kurang baik karena dibawah nilai rata-rata industri.

Return on Asset (ROA)

Nilai return on asset pada PT Express Transindo Utama pada tahun 2012 adalah sebesar 4\%, tahun 2013 sebesar $6 \%$ dan $4 \%$ pada tahun 2014 . Ini berarti setiap Rp 1,- aktiva mampu menghasilkan laba bersih 
sebesar Rp 0,04 pada tahun 2012, Rp 0,06 pada tahun 2013 dan $R p$ 0,04 pada tahun 2014. Kenaikan dan penurunan pada tahun 2013 dan 2014 disebabkan karena adanya peningkatan dan penurunan pada laba bersih. Jika dibandingkan dengan rata-rata industri nilai ROA sebelum munculnya tansportasi online adalah sebesar $5 \%$. Nilai tersebut juga kurang baik karena nilai dari ROA perusahaan sejenis pun menunjukan nilai yang kurang baik.

Sedangkan nilai return on asset pada PT Express Transindo Utama sesudah munculnya transportasi online semakin buruk. Nilai ROA pada tahun 2015 adalah sebesar 1\% turun menjadi -7\% pada tahun 2016 dan turun lagi menjadi $-24 \%$ pada tahun 2017. Penurunan tersebut diakibatkan karena perusahaan mengurangi asetnya dengan melakukan penjualan. Jika dibandingkan dengan rata-rata industri nilai ROA sesudah munculnya transportasi online menunjukan kondisi yang kurang baik karena nilainya dibawah rata-rata industri.

\section{Return on Equity (ROE)}

Nilai ROE pada PT Express Transindo Utama tahun 2012 adalah sebesar 12\% naik menjadi 17\% pada tahun 2013 lalu turun kembali menjadi 13\% pada tahun 2014. Kenaikan pada tahun 2013 disebabkan karena meningkatnya laba bersih dan penurunan pada tahun 2014 karena menurunnya laba bersih. Jika dilihat dari tingkat rasio 15-20\%, nilai ROE pada tahun 2012, 2013 dan 2014 perusahaan sudah cukup baik. Jika dilihat dari rata-rata industri, nilai ROE sebelum munculnya transportasi online adalah sebesar $14 \%$, nilai tersebut juga sudah menunjukan kondisi yang baik karena diatas nilai rata-rata indsutri.

Nilai ROE pada PT Express Transindo Utama semakin memburuk setelah munculnya transportasi online. Pada tahun 2015 nilai ROE sebesar 4\% turun menjadi -25\% pada tahun 2016 dan turun lagi menjadi -199\% pada tahun 2017. Penurunan tersebut disebabkan karena penurunan pada ekuitas dan kerugian yang terjadi setiap tahunnya. Jika dilihat dari rata-rata industri, nilai ROE sebelum munculnya transportasi online juga menunjukan kondisi yang kurang baik karena dibawah nilai rata-rata industri.

\section{Rasio Pasar PT Blue Bird, Tbk dan PT Express Transindo Utama, Tbk sebelum dan sesudah munculnya transportasi online}

\section{Earning Per Share (EPS)}

Nilai EPS pada PT Express Transindo Utama pada tahun 2012 adalah sebesar 53,5 naik menjadi 61,7 pada tahun 2013 dan turun kembali menjadi 55,3 pada tahun 2014. Peningkatan dan penurunan pada tahun 2013 dan 2014 berturut-turut disebabkan oleh meningkat dan menurunnya laba bersih. Jika dilihat dari rata-rata industri, nilai rata-rata EPS sebelum munculnya transportasi online adalah sebesar 56,83 dan nilai tersebut belum baik karena dibawah nilai rata-rata industri 182,25.

Tabel 5. Hasil perhitungan rasio pasar dan rata-rata industri sebelum dan sesudah munculnya transportasi online (2012-2017)

\begin{tabular}{|c|c|c|c|c|c|c|c|c|c|}
\hline \multirow{2}{*}{$\begin{array}{l}\text { Rasio } \\
\text { Pasar }\end{array}$} & \multirow{2}{*}{ Perusahaan } & \multicolumn{3}{|c|}{ SEBELUM } & \multirow{2}{*}{$\begin{array}{l}\text { Rata-rata } \\
\text { sebelum }\end{array}$} & \multicolumn{3}{|c|}{ SESUDAH } & \multirow{2}{*}{$\begin{array}{l}\text { Rata-rata } \\
\text { sesudah }\end{array}$} \\
\hline & & 2012 & 2013 & 2014 & & 2015 & 2016 & 2017 & \\
\hline \multirow{3}{*}{$\begin{array}{l}\text { Earning } \\
\text { Per Share }\end{array}$} & TAXI & 53,5 & 61,7 & 55,3 & 56,83 & 15,03 & $-85,99$ & -229 & -100 \\
\hline & BIRD & 404 & 333 & 336 & 357 & 329 & 203 & 170 & 234 \\
\hline & $\begin{array}{l}\text { Rata-rata } \\
\text { Industri }\end{array}$ & 209,16 & 167,71 & 169,88 & 182,25 & 99,13 & 18,56 & $-0,9$ & 38,9 \\
\hline \multirow{3}{*}{$\begin{array}{l}\text { Price } \\
\text { Earning } \\
\text { Ratio }\end{array}$} & TAXI & 16 & 24 & 21 & 20,33 & 7 & -2 & $-0,22$ & 1,6 \\
\hline & BIRD & 0 & 0 & 28,05 & 9,35 & 21,58 & 14,78 & 20,35 & 18,9 \\
\hline & $\begin{array}{l}\text { Rata-rata } \\
\text { Industri }\end{array}$ & 9 & 32 & 33 & 24,67 & 7 & 1 & 34 & 14 \\
\hline
\end{tabular}

Sumber: data diolah (2019)

Nilai EPS PT Express Transindo Utama sesudah munculnya transportasi online cukup buruk. Hal ini ditandai dengan menurunnya nilai EPS bahkan bernilai negatif. Nilai EPS tahun 2015 adalah sebesar 15,03 turun menjadi $-85,99$ pada tahun 2016 dan turun lagi menjadi -299 pada tahun 2017. Penurunan tersebut akibat dari turunnya laba bersih pada tahun 2015, 2016, dan 2017. Nilai tersebut cukup mengkhawatirkan 
bagi perusahaan, nilai EPS menunjukan berapa banyak laba yang bisa diperoleh atas kepemilikan saham pada suatu perusahaan, jika nilai EPS kecil maka laba yang diperoleh tiap lembar saham pun sedikit dan dikhawatirkan investor tidak mau menanamkan investasinya pada perusahaan tersebut.

\section{Price Earning Ratio (PER)}

Nilai PER PT Express Transindo Utama pada tahun 2012 adalah sebesar 16 yang menunjukan bahwa harga per lembar saham PT Express Transindo Utama 16 kali laba bersih yang dihasilkan perusahaan. Lalu naik menjadi 24 pada tahun 2013, kenaikan tersebut karena meningkatnya harga pasar pada tahun 2013, lalu turun lagi menjadi 21 kali pada tahun 2014. Jika dibandingkan dengan rata-rata industri, nilai rata-rata PER sebelum munculnya transportasi online termasuk dalam kategori murah karena dibawah nilai ratarata industri yaitu sebesar 24,67.

\section{PEMBAHASAN}

Nilai current ratio PT Blue Bird sesudah munculnya transportasi online cukup baik jika dibandingkan dengan sebelum munculnya transportasi online, terjadi penurunan hanya pada tahun 2015. Nilai Current Ratio pada tahun 2015 adalah sebesar 59\% meningkat menjadi 108\% pada tahun 2016 dan $177 \%$ pada tahun 2017 karena meningkatnya aset lancar, meningkatnya aset lancar tersebut dikarenakan pada tahun 2017 PT Blue Bird, Tbk. melakukan kolaborasi bersama dengan Gojek, kolaborasi keduanya terwujud dalam layanan Go-Blue Bird. Dalam layanan ini, pengguna aplikasi bisa memesan kendaraan khusus untuk taksi Blue Bird. Secara tahunan pendapatan dan laba bersih Blue Bird tahun 2017 memang menurun, namun cenderung naik apabila dilihat antar kuartal setelah melakukan kolaborasi bersama Go-jek. Jika dilihat dari tingkat rasio 100\% kinerja perusahaan pada tahun 2015 kurang baik karena dibawah 100\% dan cukup baik pada tahun 2016 dan 2017. Jika dilihat dari rata-rata industri nilai current ratio sesudah munculnya transportasi online adalah sebesar $115 \%$, nilai tersebut belum baik karena berada dibawah rata-rata industri yaitu sebesar $175 \%$.

Selanjutnya adalah rasio kas pada PT Blue Bird. Rasio kas pada tahun 2013 mengalami penurunan yang cukup signifikan yaitu $42 \%$ pada tahun 2012 turun menjadi 16\% pada tahun 2013. Penurunan tersebut karena adanya penurunan pada kas dan setara kas yang cukup besar. Namun naik menjadi $66 \%$ pada tahun 2014 karena naiknya kembali kas dan setara kas. Jika dilihat dari tingkat rasio 100\%, PT Blue Bird pada tahun 2012, 2013, dan 2014 masih kurang baik dalam memenuhi kewajiban jangka pendeknya. Namun jika dilihat dari rata-rata industri, nilai rata-rata cash ratio sebelum munculnya transportasi online adalah sebesar $41 \%$, nilai tersebut sudah cukup baik karena berada diatas nilai rata-rata industri yaitu $30 \%$. Rasio kas pada PT Blue Bird sesudah munculnya transportasi online lebih baik jika dibandingkan dengan nilai sebelum munculnya transportasi online. Kondisi kurang baik hanya terjadi pada awal munculnya transportasi online yaitu pada tahun 2015. Nilai cash ratio pada tahun 2015 adalah sebesar $28 \%$ turun dari 66\% pada tahun 2014, penurunan tersebut karena menurunnya kas dan setara kas. Pada tahun 2016 dan 2017 perusahaan meningkatkan kinerjanya kembali dengan menunjukan rasio kas sebesar 72,7\% dan $108,8 \%$. Jika dilihat dari rata-rata industri pun perusahaan masih menunjukan kinerja yang bagus karena nilainya diatas rata-rata industri.

Debt to Asset Ratio pada PT Blue Bird. Debt to Asset Ratio pada PT Blue Bird pada tahun 2012 adalah 73\% (73\% aset dibiayai oleh utang) dan naik menjadi 76\% (76\% aset dibiayai oleh utang) pada tahun 2013. Peningkatan tersebut tidak terlalu signifikan karena kenaikan utang masih diimbangi dengan kenaikan aset. Debt to Asset Ratio pada tahun 2014 mengalami penurunan menjadi 50\%, penurunan tersebut karena adanya penurunan pada utang jangka panjang dari Bank. Hal ini menandakan bahwa kinerja perusahaan cukup baik jika diukur dari Debt to Asset Ratio pada tahun 2014 karena semakin rendah rasio ini maka semakin baik. Besarnya Debt to Asset Ratio pada tahun 2012, 2013, dan 2014 masih tergolong baik karena angka rasio masih dibawah $100 \%$. Jika dilihat dari rata-rata industri, nilai rata-rata Debt to Asset Ratio sebesar $66 \%$, nilai tersebut sudah tergolong baik karena nilainya dibawah rata-rata industri yaitu sebesar $73 \%$. Nilai DAR pada PT Blue Bird sesudah munculnya transportasi online semakin baik jika dibandingkan dengan nilai sebelum munculnya transportasi online, hal ini ditandai dengan nilai DAR yang menurun setiap tahunnya. Nilai DAR pada tahun 2015 adalah sebesar 39,5\% menurun dari 50\% pada tahun 2014, lalu turun menjadi $36,1 \%$ pada tahun 2016 dan menurun lagi menjadi $24,3 \%$ pada tahun 2017. Penurunan tersebut karena adanya penurunan utang setiap tahunnya. Jika dibandingkan dengan rata-rata industri nilai rata-rata DAR pun tergolong cukup baik karena nilainya dibawah rata-rata industri. 
Nilai DER pada PT Blue Bird, nilai DER tahun 2012 sebesar 270\% naik menjadi 316\% pada tahun 2013. Kenaikan tersebut karena meningkatnya utang pada tahun 2013. Hal ini menandakan bahwa jika diukur dari Debt to Equity Ratio kinerja perusahaan pada tahun 2012 dan 2013 cukup buruk karena nilainya lebih dari 200\% yang artinya perusahaan memiliki utang yang lebih besar dari modal perusahaan. Namun perusahaan kembali meningkatkan ekuitasnya pada tahun 2014 dengan melakukan aktivitas IPO pada awal November 2014 sehingga nilai DER menurun menjadi 99\% pada tahun 2014. Jika dilihat dari rata-rata industri nilai DER sebelum munculnya transportasi online adalah sebesar $228 \%$, nilai tersebut menunjukan kondisi yang kurang baik karena nilainya diatas rata-rata industri yaitu sebesar $174 \%$. Nilai DER PT Blue Bird sesudah munculnya transportasi online semakin baik jika dibandingkan dengan nilai sebelum munculnya transportasi online. Hal ini ditandai dengan menurunnya nilai DER setiap tahunnya. Nilai DER pada tahun 2015 adalah sebesar 65,27\% turun menjadi 56,58\% pada tahun 2016 dan turun lagi menjadi $32,16 \%$. Penurunan tersebut akibat dari meningkatnya ekuitas yang disebabkan oleh IPO yang dilakukan perusahaan pada bulan November 2014. Jika dibandingkan dengan rata-rata industri juga menunjukan kinerja yang baik karena nilainya dibawah rata-rata industri.

Nilai fixed asset turn over pada PT Blue Bird. Nilai fixed asset turn over pada tahun 2012 adalah 1,01 lalu turun menjadi 0,90 pada tahun 2013 dan turun kembali pada tahun 2014 menjadi 0,86. Hal ini menunjukan bahwa perusahaan cukup baik dalam mengelola aktiva tetapnya dalam menghasilkan pendapatan pada tahun 2012 namun mulai menurun pada tahun 2013 dan 2014. Jika dilihat dari rata-rata industri nilai ratarata fixed asset turn over sebelum munculnya transportasi online adalah sebesar 0,86 dan nilai tersebut sudah dalam kategori baik karena diatas nilai rata-rata industri yaitu 0,84. Nilai fixed asset turn over pada PT Blue Bird setelah munculnya transportasi online juga semakin kurang baik hal ini ditandai dengan menurunnya nilai fixed asset turn over setiap tahunnya. Nilai fixed asset turn over turun menjadi 0,78 pada tahun 2016 dan turun lagi menjadi 0,75 pada tahun 2017. Penurunan tersebut karena perusahaan melakukan penjualan aset tetap. Namun, jika dilihat dari rata-rata industri nilai fixed asset turn over sesudah munculnya transportasi online yaitu sebesar 0,80 masih dalam kategori baik karena nilainya diatas ratarata industri.

Pada PT Blue Bird nilai total asset turn over pada tahun 2012 adalah sebesar 0,80 turun menjadi 0,78 pada tahun 2013 dan turun lagi menjadi 0,66 tahun 2014. Penurunan tersebut disebabkan karena persentase kenaikan aset lebih tinggi dari persentase kenaikan penjualan. Hal ini juga menunjukan bahwa nilai total asset turn over pada tahun 2012, 2013, dan 2014 masih belum baik karena nilainya masih dibawah 1. Jika dilihat dari rata-rata industri nilai total asset turn over sebelum munculnya transportasi online adalah sebesar 0,66 dan nilai ini sudah cukup baik karena nilainya diatas rata-rata industri yaitu sebesar 0,50. Sedangkan nilai total asset turn over sesudah munculnya transportasi online mengalami penurunan juga. Nilai TATO pada tahun 2015 adalah sebesar 0,77 turun menjadi 0,66 pada tahun 2016 dan turun lagi menjadi 0,65 pada tahun 2017. Penurunan tersebut disebabkan karena terjadi penurunan pada aset. Jika dilihat dari rata-rata industri, nilai rata-rata TATO menunjukan kondisi yang kurang baik karena nilainya dibawah rata-rata industri.

Selanjutnya adalah nilai net profit margin pada PT Blue Bird. Nilai net profit margin tahun 2012 adalah sebesar $4 \%$ naik menjadi $18 \%$ pada tahun 2013, kenaikan tersebut karena adanya peningkatan laba pada tahun 2013. Pada tahun 2014 mengalami penurunan menjadi 16\% karena persentase kenaikan pendapatan lebih besar dari persentase kenaikan laba bersih. Hal ini menunjukan bahwa perusahaan kurang baik dalam menghasilkan laba pada tingkat penjualan tertentu pada tahun 2012 karena nilainya masih dibawah $10 \%$. Jika dilihat dari rata-rata industri, nilai net profit margin sebelum munculnya transportasi online adalah sebesar $13 \%$, nilai tersebut sudah cukup baik karena diatas nilai rata-rata industri yaitu sebesar 2,6\%. Sedangkan nilai NPM sesudah munculnya transportasi online semakin kurang baik. Nilai NPM pada tahun 2015 adalah sebesar 15\% turun menjadi 10\% pada tahun 2016 dan turun lagi menjadi 10\% pada tahun 2017. Penurunan pada tahun-tahun tersebut akibat dari turunnya laba bersih. Namun jika dilihat dari rata-rata industri nilai NPM menunjukan kondisi yang masih baik karena nilainya diatas rata-rata industri.

Return on asset pada PT Blue Bird. Nilai return on asset tahun 2012 adalah sebesar 11\% naik menjadi 14\% tahun 2013 lalu turun kembali menjadi 10\% tahun 2014. Peningkatan tahun 2013 disebabkan oleh adanya kenaikan pada laba bersih dan penurunan pada tahun 2014 disebabkan oleh persentase kenaikan aset lebih tinggi dari persentase kenaikan aktiva. Jika dilihat dari rata-rata industri nilai ROA sebelum munculnya transportasi online adalah sebesar $12 \%$, nilai tersebut sudah cukup baik karena diatas nilai rata- 
rata industri. Sedangkan nilai return on asset pada PT Blue Bird sesudah munculnya transportasi online semakin buruk. Nilai ROA pada tahun 2015 adalah sebesar 12\% turun menjadi 7\% pada tahun 2016 lalu turun lagi menjadi 6\%. Jika dilihat dari rata-rata industri, nilai rata-rata ROA sesudah munculnya transportasi online sebesar $8 \%$ masih dalam kategori baik karena sama dengan nilai rata-rata industri.

Selanjutnya adalah ROE pada PT Blue Bird. Nilai ROE pada tahun 2012 adalah sebesar $42 \%$ naik menjadi 59\% pada tahun 2013 lalu turun kembali pada tahun 2014 menjadi 21\%. Hal ini menandakan bahwa pada tahun 2013 kinerja perusahaan dalam menghasilkan laba bersih dengan menggunakan ekuitas lebih baik dari pada tahun 2014. Namun jika dilihat dari tingkat rasio $15 \%-20 \%$, nilai ROE dari tahun 2012, 2013, dan 2014 sudah cukup baik. Jika dilihat dari rata-rata industri nilai ROE sebelum munculnya transportasi online juga baik karena menunjukan nilai di atas rata-rata industri yaitu sebesar $41 \%$. Sedangkan nilai ROE pada PT Blue Bird juga semakin menurun setelah munculnya transportasi online. Nilai ROE pada tahun 2015 adalah sebesar 19\%, turun menjadi 11\% ada tahun 2016 dan turun lagi menjadi 9\% pada tahun 2017. Penurunan tersebut disebabkan karena terjadinya penurunan laba bersih. Jika dilihat dari rata-rata industri nilai ROE sesudah munculnya transportasi online yaitu sebesar $13 \%$ sudah menunjukan kinerja yang masih baik karena nilainya diatas nilai rata-rata industri.

PT Blue Bird, pada tahun 2012 - 2013 belum melakukan go public. Walaupun pada tahun 2012 dan 2013 belum melakukan go public, informasi mengenai jumlah rata-rata tertimbang saham bisa dapat diketahui pada laporan keuangan tahunan 2014. Tingkat EPS pada tahun 2012, 2013, dan 2014 cenderung stabil yaitu berturut- turut 404, 333, dan 336. Jika dilihat dari rata-rata industri nilai rata-rata EPS sebelum munculnya transportasi online cukup baik karena nilainya diatas rata-rata industri yaitu 182,25. Nilai EPS PT Blue Bird menurun setelah munculnya transportasi online. Nilai EPS pada tahun 2015 adalah sebesar 329 turun menjadi 203 pada tahun 2016 dan turun lagi menjadi 170 pada tahun 2017. Penurunan tersebut disebabkan karena menurunnya laba bersih Namun jika dilihat dari rata-rata industri nilai rata-rata EPS masih dalam kategori baik karena nilainya diatas rata-rata industri yaitu sebesar 38,9.

Nilai PER PT Express Transindo Utama sesudah munculnya transportasi online mengalami penurunan. Nilai PER pada tahun 2015 adalah 7 turun menjadi -2,00 pada tahun 2016 dan turun lagi menjadi -0,22 pada tahun 2017. PER negatif akibat dari kerugian yang dialami oleh perusahaan. Selain itu, penurunan pada PER disebabkan oleh anjloknya harga saham setelah munculnya transportasi online. Harga saham pada tahun 2015, 2016, dan 2017 berturut-turut adalah 105,170, dan 50. Sedangkan pada PT Blue Bird, pada tahun 2012 dan 2013 nilai PER tidak dapat diketahui karena belum melakukan IPO. Nilai PER tahun 2014 adalah sebesar 28,05 yang artinya harga per lembar saham PT Blue Bird Utama 28,05 kali laba bersih yang dihasilkan perusahaan. Nilai PER PT Blue Bird mengalami penurunan setelah munculnya transportasi online. Nilai PER pada tahun 2015 adalah sebesar 21,58 kali turun menjadi 14,78 pada tahun 2016 dan naik menjadi 20,35 pada tahun 2017. Hal ini juga disebabkan karena adanya penurunan pada laba bersih dan harga pasar saham. Harga pasar saham pada tahun 2015, 2016, dan 2017 berturut-turut adalah 7.100, 3.000, dan 3.460 .

\section{SIMPULAN DAN SARAN}

\section{SIMPULAN}

Rasio Likuiditas PT Express Transindo memiliki current ratio dan cash ratio yang kurang baik sesudah munculnya transportasi online. Namun jika dilihat dari rata-rata industri current ratio masih dalam kondisi baik karena berada diatas nilai rata-rata industri. Sedangkan cash ratio berada dibawah rata-rata industri. Pada PT Blue Bird, nilai current ratio dan cash ratio cukup baik setelah munculnya transportasi online. Namun jika dilihat dari rata-rata industri current ratio belum baik karena nilai berada dibawah rata-rata industri. Sedangkan rasio kas berada diatas rata-rata industri. Rasio Solvabilitas PT Express Transindo Utama memiliki nilai Debt to Asset Ratio dan Debt to Equity Ratio yang kurang baik setelah munculnya transportasi online, nilai rata-ratanya pun berada diatas nilai rata-rata industri. Pada PT Blue Bird, nilai Debt to Asset Ratio dan Debt to Equity Ratio menunjukan nilai yang semakin baik setelah munculnya transportasi online, nilai rata-ratanya juga berada dibawah nilai rata-rata industri. Rasio Aktivitas PT Express Transindo Utama menunjukan nilai fixed asset turn over dan total asset turn over yang menurun setelah munculnya transportasi online, nilai rata-ratanya pun berada dibawah nilai rata-rata industri. Begitupun pada PT Blue Bird menunjukan nilai fixed asset turn over dan total asset turn over yang menurun 
setelah munculnya transportasi online, namun nilai rata-ratanya masih dalam kondisi yang baik karena berada diatas nilai rata-rata industri. Rasio Profitabilitas PT Express Transindo Utama memiliki nilai NPM, ROA, dan ROE yang kurang baik setelah munculnya transpotasi online. Nilai rata-ratanya pun berada dalam kondisi negatif dan dibawah nilai rata-rata industri. Sedangkan pada PT Blue Bird nilai NPM, ROA, dan ROE cenderung menurun setelah munculnya transportasi online, namun nilai rata-ratanya masih diatas nilai rata-rata indusri. Rasio Pasar PT Express Transindo Utama memiliki nilai EPS dan PER yang kurang baik setelah munculnya transportasi online. Nilai rata-ratanya pun menunjukan kondisi negatif dan dibawah rata-rata industri. PT Blue Bird juga memiliki nilai EPS dan PER yang kurang baik setelah munculnya transportasi online namun nilai rata-ratanya masih diatas nilai rata-rata industri.

\section{SARAN}

Bagi PT Express Transindo Utama dan PT Blue Bird harus meningkatkan lagi tingkat likuiditasnya terutama dalam mengelola aset lancarnya yaitu kas dan setara kas. Untuk tingkat solvabilitas, PT Express Transindo Utama sebaiknya mengurangi lagi utangnya untuk mengurangi risiko yang akan dihadapi perusahaan. Sedangkan pada PT Blue Bird tetap mempertahankan tingkat solvabilitasnya karena menunjukan kondisi yang semakin baik. Dalam aktivitasnya, PT Express Transindo Utama dan PT Blue Bird harus meningkatkan lagi tingkat aktivitasnya dengan meningkatkan penjualan. Meskipun persaingan bisnis semakin meningkat akibat adanya transportasi online, kedua perusahaan dapat beralih untuk memiliki layanan online sehingga tidak kalah bersaing dengan transportasi online. Dari tingkat profitabilitas, PT Express Transindo Utama sebaiknya meningkatkan lagi tingkat profitabilitasnya dengan meningkatkan laba bersih pada perusahaan. Dari dari rasio pasar yang semakin menurun, sebaiknya PT Express Transindo Utama dan PT Blue Bird meningkatkan lagi kemampuan dalam menghasilkan laba bersih tiap lembar sahamnya agar harga saham bisa meningkat dan para investor mau menanamkan investasi pada perusahaan.

\section{DAFTAR PUSTAKA}

Achmad, Suryana. (2003). Kapita Selekta Evolusi Pemikiran Kebijakan Ketahanan Pangan. Yogyakarta: FE UGM.

Arikunto, S. (2006). Metodologi Penelitian. Yogyakarta: Bina Aksara.

Bagus Yanuar, (2009). Analisis Pengaruh Akuisisi Terhadap Kinerja Perusahaan (Studi Empiris Pada Pt. Sampoerna Tbk Di Bursa Efek Indonesia). Fakultas Ekonomi. Universitas Muhammadiyah Surakarta.

Chandrarin, Grahita .(2017). Metode Riset Akuntansi Pendekatan Kuantatif. Salemba Empat. Jakarta.

Dewi, Sevika Ranita. (2015). Analisa Perbandingan Kinerja Keuangan BeberapaPerusahaan Sebelum dan Sesudah Akuisisi (Studi Pada Perusahaan Pengakuisisi yang Terdaftar di BEI Periode 2003-2013). Jurnal Ekonomi dan Bisnis. Universitas Dian Nuswantoro

Fahmi, Irham. (2012). Analisis Laporan Keuangan. Cetakan ke-2. Bandung: Alfabeta

Ghozali, Imam. (2013). Aplikasi Analisis Multivariate dengan Program IBM SPSS 21 Update PLS Regresi. Badan Penerbit Universitas Diponegoro. Semarang Istianto, Bambang; Maulamin, Taufan (2017). Kebijakan Transportasi On Line Dan Konflik Sosial, Jurnal Ilmu asdministrasi negara ASIAN, Vol 5 No. 2

Kompas.com. (2017). Bentrok Transportasi Konvensional dan Online, diakses dari https:// www.google.co.id/amp/s/amp.tirto.id/bentrok-transportasi-konvensional-dan-online-clvq, pada 28 November 2018 tirto.id. 2017.

Kasmir. (2014). Analisis Laporan Keuangan.Jakarta : PT Raja Grafindo Persada

Satriyono, G., \& Kristanti, D. (2018). Pengaruh Kepuasan Pasien Pada Kualitas Layanan Rawat Inap Terhadap Niat Discharge Against Medical Advice (Dama) (Studi di Rumah Sakit Umum Daerah Pare Kabupaten Kediri). Ekonika: Jurnal Ekonomi Universitas Kadiri, 3(2), 33. https:// doi.org/10.30737/ekonika.v3i2.190

Satriyono, G., \& Ruhamak, M. D. (2017). Analisis Kesenjangan Antara Ekspektasi Konsumen Terhadap 
Persepsi Jasa Pelayanan (Studi Kasus pada Bengkel Cat dan Las Mobil Warna Indah di Kediri). Ekonika : Jurnal Ekonomi Universitas Kadiri, 2(2), 142. https://doi.org/10.30737/ekonika.v2i2.39

Sari Fazry, (2017). Pengaruh Terpaan Iklan Online Go - Jek Indonesia Terhadap Tindakan Menggunakan Jasa (Studi Pada Penggunaan Go - Jek di RT 07/RW 07 Perumahan Bukit Cemara Tujuh) Other Thesis - University Of Muhammadiyah Malang.

Siregar, Doni., (2014). Dampak Kehadiran PT.Sumatra Speciality Coffe (SSC) Terhadap Sosial Ekonomi Masyarakat Desa Pohan Tonga Kecamatan Siborong Kabupaten Tapanuli Utara. 